\title{
Analysis and evaluation of distributed photovoltaic generation in electrical energy production and related regulations of Turkey
}

\author{
Mehmet Çeçen ${ }^{1,3}$ (1) Cenk Yavuz ${ }^{2,3} \cdot$ Ceyda Aksoy Tırmıkçı ${ }^{2,3} \cdot$ Sinan Sarıkaya ${ }^{4} \cdot$ Ertan Yanıkoğlu $^{3}$
}

Received: 3 August 2021 / Accepted: 28 November 2021 / Published online: 7 January 2022

(c) The Author(s), under exclusive licence to Springer-Verlag GmbH Germany, part of Springer Nature 2021

\begin{abstract}
Turkey is a developing country with rising energy demands. Energy access is one of the key parameters to sustain the development, since the country meets a considerable part of energy demands by imported fossil fuels. Distributed photovoltaic power generation (DPPG) is one of the sustainable solutions to increase renewable energy sources (RES) shares in primary energy demand. This paper investigates Turkey's current policy system with its excellences and shortcomings in different stages of distributed photovoltaic power generation development in the country. By the assessment of the current situation, a strengths (S) and weaknesses (W) and external opportunities $(\mathrm{O})$ and threats $(\mathrm{T})$ analysis is also conducted to propose urgent strategies to contribute the development of DPPG sector in Turkey. In conclusion, future roles of the government and energy market are discussed to increase integration of DPPG in Turkish renewable energy market comprehensively.
\end{abstract}

\section{Graphical abstract}

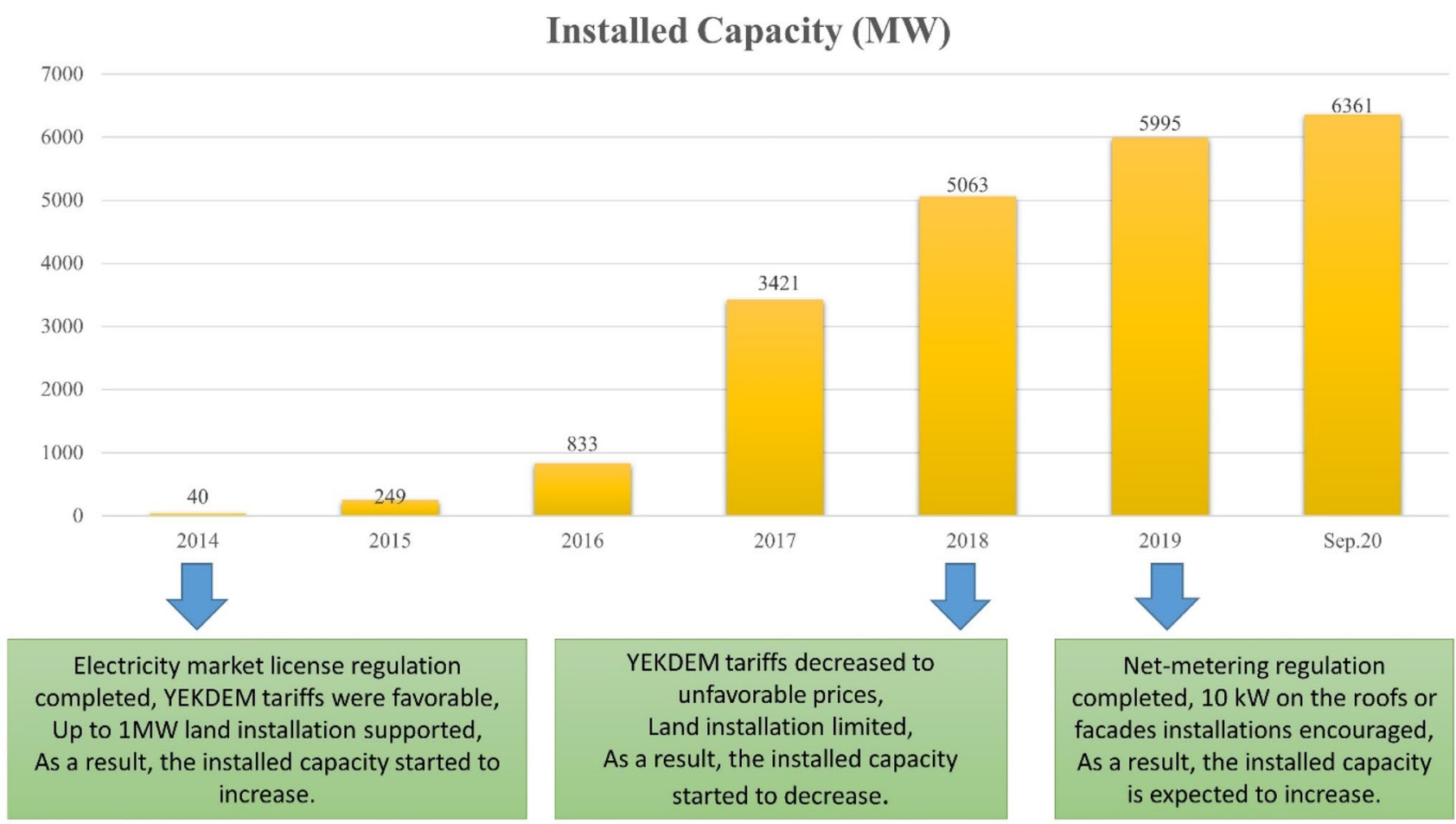

Keywords Renewable energy $\cdot$ Solar energy $\cdot$ Distributed photovoltaic generation $\cdot$ Regulation $\cdot$ SWOT

Extended author information available on the last page of the article 


\section{Introduction}

There is a fast-growing global energy demand due to the growth in the global economy and population. In 2010, global primary energy consumption was 12 billion tons of oil equivalent (btoe) and reached to 13.2 btoe in 2016 . Fossil fuel resources had the largest share in this number, $87 \%$. The rest is renewables with $7.8 \%$ and nuclear with $5.2 \%$. The reports indicate that global demand for energy is expected to grow by almost a third by 2040. Global goals for a sustainable development are to meet the rising demands for all in affordable and reliable ways with a greater share of natural gas and RES (BP Energy Outlook 2018).

Natural gas shares in global energy consumption increased $4.6 \%$ in 2018 and met almost half of the increase in total demand. It is a fact that natural gas is the cleanest fossil fuel and shares of natural gas in energy market are expected grow at least $2.3 \%$ annually supporting the transition to renewables (BP Energy Outlook 2019). The most essential issue of sustainable development goals is to increase the integration of renewable energy technologies in the power sector while continuing to enhance energy access for all. In recent years, renewable energy applications have expanded dramatically due to improving energy policies and developing market. Renewable energy shares are expected to grow at least by $8.2 \%$ by 2030 (BP Energy Outlook 2019).

Rising shares of natural gas and renewables in global energy demand brings a decline in global coal use. The reports indicate that coal-based power generation dropped by $3 \%$ in 2019 which was recorded highest in 2018 . The scenarios claim that the decline will continue and reach to $275 \mathrm{GW}$ at least by 2025 (Özenç 2020).

The world has accelerated energy transitions within the frame of sustainable energy development goals to provide clean, reliable, and affordable energy for all. Therefore, power systems have been experiencing a significant change due to renewable energy growth, distributed energy generation growth and developing digitalization (BP Energy Outlook 2020). One of the main targets of European energy policy target is to expand clean energy capacity in parallel with the growth in energy demands. The reports indicate that renewable shares in total European energy generation are expected to be $32 \%$ by 2030 (European Union 2009; European Commission 2020). EU countries are either phasing out coal or have set a phase-out date. Coal use is expected to decrease by $70 \%$ compared to 2015 . Renewable electricity is expected to reach $60 \%$ of electricity produced by 2030 (2030 Climate Target Plan 2020). Considering that the European Union aims zero net emissions by 2050 within the frame of European Green Deal, coal-fired power generation is likely to be phased out before 2060 (Kirova and Velikova 2016).
Distributed generation (DG) is defined as electrical generation by a grid-connected or distribution system-connected distributed energy system close to the load. A variety of energy technologies can be used to power DG systems. In recent years, the number of renewable forms of DG systems increase rapidly, especially in developing countries, since they offer sustainable energy for consumers (Brass et al. 2012). In clean energy transition policies, one of the main targets is to make the consumers to meet their own energy demands by RES on-site or nearby. Thus, incentive actions for DG systems play an important role in achieving the energy part of sustainable development goals. However, energy frameworks of many countries requires reforms to add renewables into their grids (IEA 2017b). Thus, several action plans have been put in place recently to increase renewable shares in global primary energy consumption (IFC 2017). Therefore, distributed photovoltaic (PV) power generation (DPPG) has become one of the main options for RES development in many countries.

Distributed photovoltaic power generation specifically refers to the generation of electrical energy from solar energy directly through photovoltaic modules. DPPG systems are integrated into the grid, unlike off grid systems. The generated electrical energy is transferred to the grid by making a connection from the closest point. DPPG systems are not considered as systems that only provide electrical energy to the grid. These systems also have the effect of improving the grid voltage and power quality. Grid-connected distributed photovoltaic systems can be installed to supply energy to a specific consumer or directly to the grid (Hoff 2007). With these features, there is an increasing interest in DPPG worldwide.

In 2019, the share of renewables in global energy generation rose $6 \%$ with new installed global solar, wind hydro-capacity additions to a record $200 \mathrm{GW}$ (REN21 2020). Increasing interest in DG systems due to environmental concerns and electricity market liberalization is the main driver force for the growth in renewables capacity. Among all renewables, solar technologies are one of the most common approaches preferred in DG systems. The reports indicate that solar photovoltaic capacity additions are recorded $22 \%$ in 2019 and it is likely to observe higher additions in coming years with an urgent recovery of distributed solar PV policies worldwide (IEA 2020a). In 2019, global installed distributed solar PV capacity is recorded a historic value, $627 \mathrm{GW}$, with new additions to a record $115 \mathrm{GW}$ (IEA 2020b). The largest share of global DPPG comes from China, 204.7 GW (Li et al. 2020). Europe follows China with $131.7 \mathrm{GW}$ total installed distributed solar PV capacity. The USA and Japan are the following contributors with $75.9 \mathrm{GW}$ and $63.2 \mathrm{GW}$ capacity, respectively (IEA 2019b). Germany is the leading country for DPPG in Europe with an installed capacity 
of 49.2 GW (BP Statistical Review 2019). In 2019, 28 countries met $131.8 \mathrm{TWh}$ of total primary energy demand by DPPG systems and increased solar PV share in global energy generation to 4\% (EurObserv'ER 2020). In the last decade, solar PV demand of developing countries has grown dramatically $44 \%$ excluding China the largest PV market globally (Li 2017). Therefore, it is expected that cumulative installed distributed solar PV generation capacity will reach to a record 1 TW by 2030 (Waldau 2019).

In Turkey, policy momentum in renewable energy market has boosted distributed solar PV capacity since 2014 . The share of solar PV in total installed power capacity reached to 6.5\% in September 2020 with total installed solar PV capacity to a record $6.36 \mathrm{MW}$. It is expected to rise the share of renewables in total installed power capacity to 38.8 by 2023 (Strategy and Budget Department 2019). The target for installed solar capacity is reported 10 GW (MENR 2019).

In 2020, the population of Turkey was 83.6 million with a growth rate of $0.55 \%$ on annual basis (TSI 2018a). Electricity consumption of the country increased from 0.9 $\mathrm{MWh} /$ capita in 1990 to $3.3 \mathrm{MWh} /$ capita in 2019 in parallel with the consistently growing population. In 2019, coal was the primary source for electricity generation with a record 113,218 GWh followed by hydro and natural gas. The reports indicate that 190 ktoe of electricity fossil fuel resources demand was met by imports within the same year (IEA 2020c). The dependency on imports is a major energy policy challenge facing the country to promote sustainable development goals. Therefore, it is an urgency for Turkey to achieve the liberalization of its electricity and natural gas markets for a reliable, sustainable and affordable energy future. In this regard, distributed photovoltaic power generation appears to be one of the most effective solutions for the country. In recent years, several reforms have been made within Turkey's energy framework to increase solar share in energy generation (MENR 2019).

The main objective of this paper is to investigate Turkey's distributed solar PV policy with its challenges, SWOT analysis of DPPG and to discuss urgent incentive action plans to put in place for further policy improvements. The organization of the paper is as follows. See section 'Turkey's electrical energy status' presents Turkey's electrical energy status. See section 'Solar energy potential of Turkey' discusses solar energy potential of Turkey. See section 'Solar energy legislations and incentives' reviews Turkey's solar energy legislations and supports. See section 'Solar energy in Turkey' introduces solar energy status in Turkey. See section 'SWOT analysis of DPPG in Turkey' introduces SWOT analysis of DPPG in Turkey. See section 'Conclusion' presents the conclusions.

\section{Turkey's electrical energy status}

Turkey is a transcontinental country straddling Asia and Europe bordered by Georgia, Armenia, Azerbaijan, Iran, Syria, Greece, and Bulgaria. The country is a developing and urbanizing regional power with a significant geopolitical position, an energy transit corridor between East and West. Turkey is classified as an upper-middle income country in terms of its GDP, the world's 17th largest nominal GDP. In the last decade, the country achieved an impressive economic development in many sectors and in 2017, the economic growth is recorded $7.4 \%$, the second largest growth in Europe. Although there has been a slowdown, the country's economy grew $2.6 \%$ in 2018 and $0.9 \%$ in 2019 (TSI 2018b).

Turkey has an increasing energy demand growth rate over the last 15 years in parallel with the steady growth in its economy. Table 1 presents the country's installed electrical power capacity and energy generation by primary energy resources. Installed capacity consists of $28.1 \%$ natural gas, $22.2 \%$ coal (hard coal + imported coal), $31.2 \%$ hydro (run of river (river + storage)), $8.5 \%$ wind, $6.7 \%$ solar and $3.3 \%$ other sources (TEIAS 2020a). According to the table, $59.14 \%$ of Turkey's electrical energy production is met by fossil fuels, and $40.86 \%$ renewable sources. Total imported fossil fuel rate is $43.14 \%$ in all electric energy production. Hydropower is the source with the largest share with $28.23 \%$. DPPG has the least share with $0.12 \%$. Turkey meets most of its energy

Table 1 Installed power and number of power plants by primary sources (TEIAS 2020b)

\begin{tabular}{llrl}
\hline Fuel type & $\begin{array}{l}\text { Installed power } \\
(\mathrm{MW})\end{array}$ & Unit & Production $(\mathrm{GWh})^{*}$ \\
\hline Hydro (river type) & 7912.70 & 562 & $21,075.77$ \\
Asphaltite coal & 405 & 1 & 2410.36 \\
Waste heat & 369.6 & 84 & 0 \\
Hydro (dam type) & $21,877.10$ & 128 & $59,919.56$ \\
Biomass & 868.8 & 196 & 3774.42 \\
Naturel gas & $25,632.30$ & 335 & $59,520.72$ \\
Fuel oil & 305.9 & 11 & 311.98 \\
Solar & 6361.30 & 7267 & 357.67 \\
Imported coal & 8966.90 & 15 & $64,116.71$ \\
Geothermal & 1514.70 & 54 & 9170.79 \\
Lignite & $10,097.30$ & 47 & $39,959.79$ \\
LNG & 2 & 1 & 0 \\
Diesel & 1 & 1 & 0 \\
Naphtha & 4.7 & 1 & 0 \\
Wind & 8077.00 & 283 & $23,108.38$ \\
Stone coal & 810.8 & 4 & 3610.54 \\
Total & $93,207.1$ & 8990 & $287,336.69$ \\
\hline
\end{tabular}

*Electric production period: 01.09.2019-01.09.2020 (EPİAŞ 2021) 
demand from fossil fuels, and heavy dependence on fossil fuel imports rises as the largest vulnerability of the country's sustainable development goals.

The number of power plants providing power to interconnected system has increased dramatically since 2016 by the introduction of the roof legislation for small power solar energy systems. In 2015, it was recorded that electric power of the country was generated at 1521 power generating stations. The number of total generating stations were recorded 2321 by the end of 2016,5021 by the end of 2017,7234 by the end of 2018,8589 by the end of 2019 and 8990 by September 2020 (TEIAS 2020b).

Figure 1 indicates the total installed electricity power by years. According to the figure, Turkey has experienced a rapid growth in power sector by the end of 2016. In 2015, the total installed capacity was recorded $73,173 \mathrm{MW}$ and reached to $93,207.1$ MW by September 2020 with annual growth rates of $7.4 \%$ for $2016,8.42 \%$, for $2017,3.93 \%$ for 2018, 3.07\% for 2019 (TEIAS 2020b).

In Turkey, developing economy and growing population push demand for energy firmly up. Despite the economic slowdown in 2008, electricity consumption of the country increased by an average of 5.4\% between 2002 and 2019 (TEDAS 2018). Electricity consumption data given in Fig. 2 indicate that the demand doubles approximately every ten years.

One of the key parameters of sustainable development is to ensure energy access for all. Turkey's rapid growth
Fig. 1 Installed power capacity change by years of Turkey (end of September 2020) (TEIAS 2020b)

Fig. 2 Total electric energy consumption of Turkey by years (TEIAS 2020a)
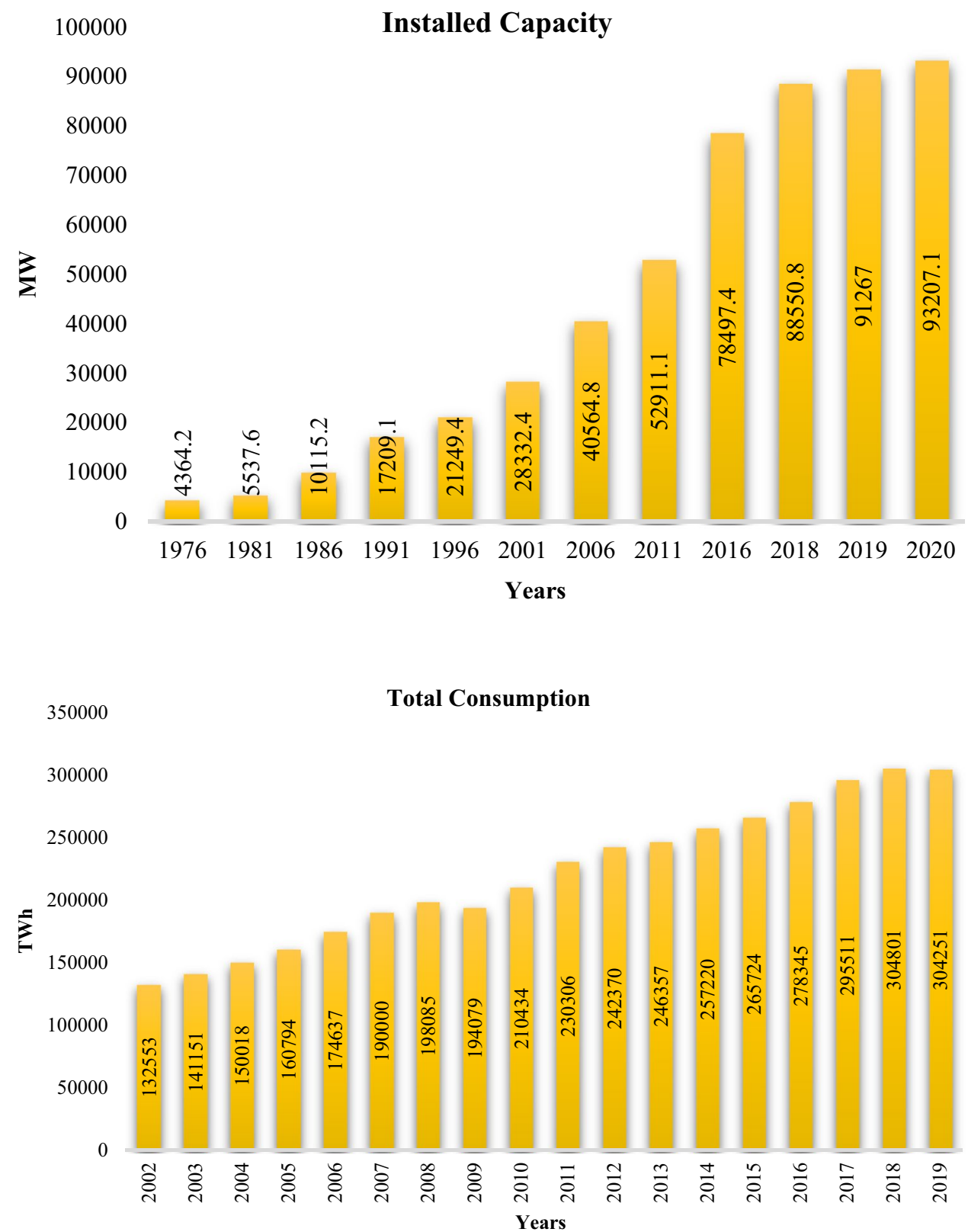
in energy demand has heavily increased fossil fuel import dependency. Thus, the country has prioritized clean, reliable and affordable energy access within sustainable development goals. Boosting domestic energy resources, accelerating renewable energy transitions and improving energy efficiency are the main pillars of the country's energy strategy.

Turkey has made particular progress increasing the share of renewables in energy generation as well as boosting domestic fossil fuel sources within its energy strategy. The country aims to increase the ratio of electricity installed power based on domestic and RES to total installed power from 59 to $65 \%$ by 2023 (MENR 2019). The target for installed solar power has been announced as 10,000 MW. However, the European Union plans to provide 32\% of electricity generation from RES by 2030 . The proliferation of distributed and renewable source power plants is critical to achieving the stated goals.

\section{Solar energy potential of Turkey}

There are two main types of solar energy technologiesphotovoltaic solar technology to convert sunlight into electricity and solar thermal technology to capture the sunlight's heat. In recent years, solar PV technologies have seen stable growth with sustainable policy transitions worldwide. It is expected that solar PV market continues to grow with significant capacity additions from off-grid applications up to utility-scale power generation plants. Solar thermal technology applications also increased in parallel with sustainable development concerns. However, it is likely to see a higher growth in the market in the following years with smooth policy transitions (IEA 2017a).

Turkey is located in the northern hemisphere between 36 and $42^{\circ}$ north latitude and $26-45^{\circ}$ east longitude. The country is located closer to the equator than the poles straddling Western Europe and Southern Asia. The geographical position provides the land an enormous solar energy potential with the mean annual solar radiation of $1527 \mathrm{kWh} /$ $\mathrm{m}^{2}$-year. Turkey has a favorable theoretical potential in comparison with many European countries like Germany, France and Italy with theoretical potentials of $1014 \mathrm{kWh} / \mathrm{m}^{2}$-year, $1248 \mathrm{kWh} / \mathrm{m}^{2}$-year and $1448 \mathrm{kWh} / \mathrm{m}^{2}$-year, respectively (IEA 2019a).

The Ministry of Energy and Natural Resources (MENR) made Turkey's solar energy assessment based on measured accurate data by the Turkish State Meteorological Service (TSMS) recently. The assessment indicated that the annual total sunshine duration was $2640 \mathrm{~h}$ and mean annual solar radiation was $1311 \mathrm{kWh} / \mathrm{m}^{2}$-year. However, TSMS developed solar radiation models based on the results of the assessment by MENR and solar radiation data measured by TSMS's 157 weather stations in 1971 and 2000. The models of TSMS established that the annual total sunshine duration was $2573 \mathrm{~h}$ and mean annual solar radiation was $1527 \mathrm{kWh} /$ $\mathrm{m}^{2}$-year. Table 2 shows the monthly and regional solar energy potential of Turkey determined by TSMS, respectively (MENR 2021a).

In 2010, MENR published the Turkey Solar Energy Potential Atlas (GEPA) given in Fig. 3, which is an important resource for solar energy feasibility studies. The GEPA was obtained with the ESRI solar radiation model which combines the region's solar radiation, topography and seasonal data. Long-term data measured by 148 TSMS stations and 8 MENR stations in 1985 and 2006 were used to calculate model parameters and to calibrate the model (MENR 2021b).

Turkey's annual solar radiation level ranges from $1400 \mathrm{kWh} / \mathrm{m}^{2}$-year in the Black Sea region to $2000 \mathrm{kWh} / \mathrm{m}^{2}$ year in the South East and Mediterranean regions (Fig. 3). Table 3 shows the monthly mean daily solar radiation and sunshine duration in Turkey (Sensoy et al. 2010).

\section{Solar energy legislations and incentives}

In the Turkish electricity market, there is no separate legislation for regulations on solar energy and other RES. From a legal point of view, supports for utilization of solar energy in electricity generation and encouraging investment in solar energy are generally evaluated together with other RES. Among these regulations, the most important ones are the Law No. 5346 on the Utilization of Renewable Energy Resources for the Purpose of Electricity Generation (YEKK), the Law No. 6094 amending the Law No. 5346, the Electricity Market Law No. 6446 (EPK) and the Energy Efficiency Law No. 5627 (EVK). The Electricity Market License Regulation (EPLY), the Unlicensed Electricity Production Regulation (LEÜY), the Regulation on Domestic Manufacturing of the Parts Used in the Facilities Producing Electricity from RES and the Renewable Energy Resources Area (YEKA) Regulation introduce these laws.

Table 2 Regional solar radiation and sunshine duration of the country (MENR 2021a)

\begin{tabular}{lll}
\hline $\begin{array}{l}\text { Geographical region of } \\
\text { Turkey }\end{array}$ & $\begin{array}{l}\text { Monthly total solar } \\
\text { radiation }\left(\mathrm{kWh} / \mathrm{m}^{2}-\right. \\
\text { month) }\end{array}$ & $\begin{array}{l}\text { Sunshine } \\
\text { duration } \\
\text { (hours/year) }\end{array}$ \\
\hline Southeastern anatolia & 1648 & 2845 \\
Mediterranean & 1548 & 2737 \\
East anatolia & 1523 & 2519 \\
Central anatolia & 1481 & 2563 \\
Aegean & 1528 & 2615 \\
Marmara & 1329 & 2250 \\
Black Sea & 1305 & 1929 \\
\hline
\end{tabular}




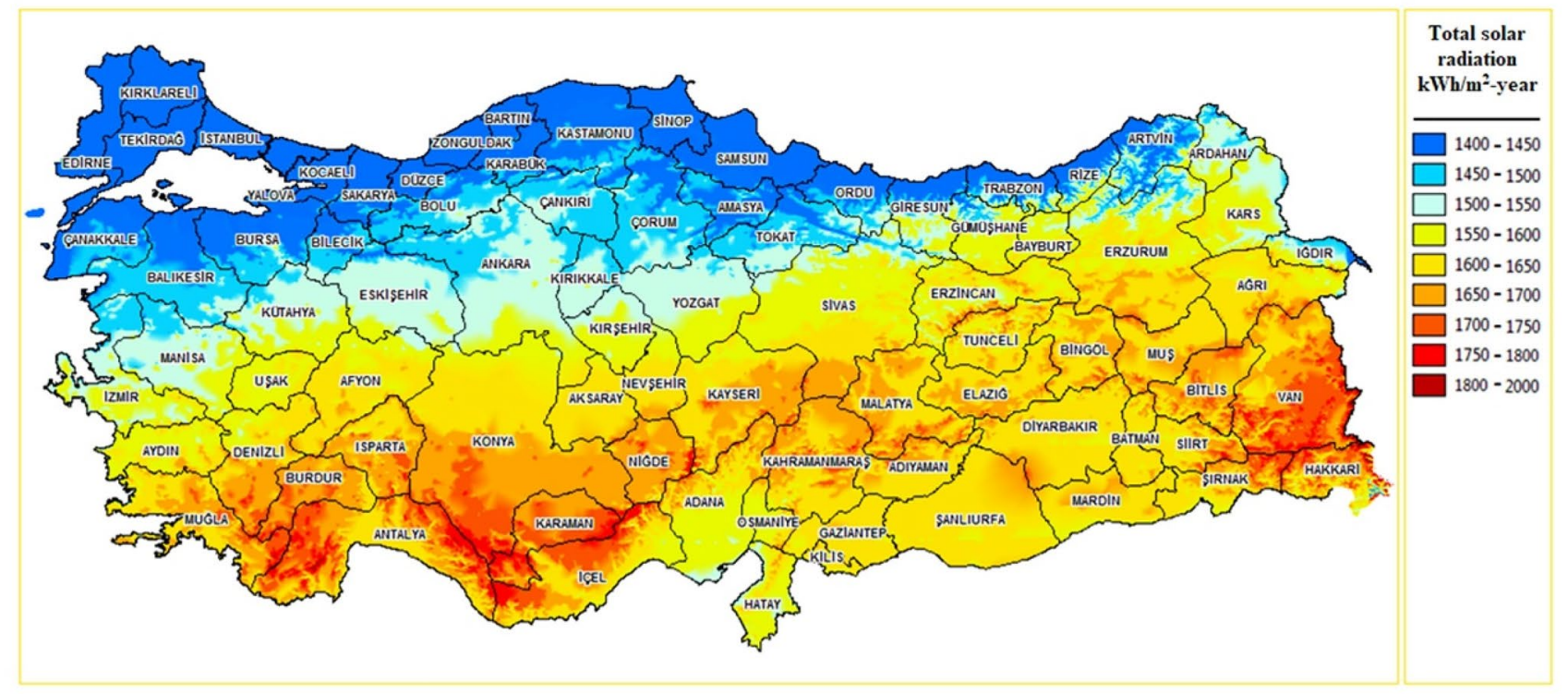

Fig. 3 Turkey Solar Energy Potential Atlas (MENR 2021b)

Table 3 Monthly variation of average daily solar radiation and insolation duration in Turkey (MENR 2021b)

\begin{tabular}{lll}
\hline Month & $\begin{array}{l}\text { Average daily solar radia- } \\
\text { tion }\left(\mathrm{kWh} / \mathrm{m}^{2} \text {-day }\right)\end{array}$ & $\begin{array}{l}\text { Average daily insola- } \\
\text { tion duration (hour/ } \\
\text { day) }\end{array}$ \\
\hline January & 1.79 & 4.11 \\
February & 2.5 & 5.22 \\
March & 3.87 & 6.27 \\
April & 4.93 & 7.46 \\
May & 6.14 & 9.1 \\
June & 6.57 & 10.81 \\
July & 6.5 & 11.31 \\
August & 5.81 & 10.7 \\
September & 4.81 & 9.23 \\
October & 3.46 & 6.87 \\
November & 2.14 & 5.15 \\
December & 1.59 & 3.75 \\
\hline
\end{tabular}

\section{Renewable energy generation models}

Legal regulations and support mechanisms created to increase the use of RES in electricity production in Turkey generally take place in the form of two production and application models. These models consist of unlicensed and licensed energy production from RES.

Contrary to the world countries, there are no clear statements defining the capacity of distributed generation systems in the legislation studies on the Turkish electricity market. Instead, only the connection points to the grid according to the system power are defined for grid integration of RES distributed generation systems. DG is connected to the distribution system from the low voltage (LV) level, if the DG installed power is $11 \mathrm{kWeq}$ or less. However, the connection point can be from LV level and/or high voltage (HV) level, if the DG installed power is over $11 \mathrm{kWeq}$ (MENR 2021a). In addition, in the unlicensed generation model, the installed power of DG power plants is limited to a maximum of $5 \mathrm{MW}$.

The total installed power of 25 power plants operated under the licensed generation model from solar energy is 258.9 MW (OG 2011b). The tender for the first power plant to produce according to the YEKA regulation, which is also evaluated under the licensed generation model, was made in 2017. This project, named YEKA-GES-1, which is expected to have an installed power of $1 \mathrm{GW}$, will be the largest solar project in Turkey when it is completed (OG 2016). The YEKA-GES-3 tender has been planned, and the calendar has been announced. With this call, different from YEKAGES-1, 74 different projects will be implemented across Turkey with 10 MWeq, 15 MWeq and 20 MWeq installed powers (OG 2020). In this article, all grid-connected solar power plants are considered as DPPG due to their installed power except for the YEKA-GES-1 project. DPPG systems can find a place for itself in both models (licensed and unlicensed) with the current legislation and application forms.

\section{Unlicensed generation model}

Natural or legal persons were allowed to install renewable energy systems that produce up to $500 \mathrm{~kW}$ of energy without the need for a license with the Law No.5346 on YEKK. The maximum installed power that can be produced without a license was first increased to $1 \mathrm{MW}$ with the EVK issued in 
2007, and to $5 \mathrm{MW}$ with the Presidential Decree (CK) dated 9 May 2019 and numbered 1044 (OG 2007, 2019a).

In unlicensed installations, unlike licensed installations, there is no obligation to establish a company, to schedule inconnection timeline or to collect measurement data for the area where the installation will be made. According to the new regulation, private real persons or legal entities are only able to apply for roof or facade institutions with a capacity of up to $5 \mathrm{MW}$, provided that the contract power of the relevant facility is not exceeded. According to the regulation, the generation facility and the consumption facility must be at the same connection point. Only public institutions are granted the right to establish ground-mounted generation facilities with a different connection point from consumption facilities, provided that they do not exceed the contractual power.

Land establishment permits have been terminated as of 2018. Land installations with CK can only be made by public institutions and organizations. In accordance with the relevant DPPG systems and components domestic generation regulation, local content support has been terminated for unlicensed projects, unlike licensed projects (OG 2019a).

Within the scope of the unlicensed generation regulation, roof and facade installations up to $10 \mathrm{~kW}$ are evaluated separately from other installations of more than $10 \mathrm{~kW}$ in terms of application processes. In January 2018, the Energy Market Regulatory Authority (EMRA) published the board decision dated 28/12/2018 and numbered 7590 in order to facilitate and encourage solar energy installations up to $10 \mathrm{~kW}$ (OG 2017). The application and excess power purchasing procedures and principles of unlicensed solar power generation facilities with the same connection point as the consumption facility have been determined with the board decision. In addition, with the Official Gazette dated 27/03/2018, households who sell excess electricity generated from DPPG installed up to $10 \mathrm{~kW}$ on the roofs or facades of their residences are exempt from income tax for incentive (OG 2007).

The Law No.1044 on CK announced significant changes for the establishment and promotion of unlicensed power generation facilities. With the decree, the unlicensed generation capacity limit was increased from 1 to $5 \mathrm{MW}$ and monthly offsetting has been introduced for the first time. The electricity purchase price has been determined as the standard retail price for all unlicensed generation plants of $10 \mathrm{~kW}$ and above for the first ten years after the installation is commissioned. For households, the maximum installed power of DPPG is determined as $10 \mathrm{~kW}$ for roof and facade installations. Retail electricity prices subject to monthly offsetting are updated quarterly by EMRA for different types of consumers such as industry users, commercial users and household users (OG 2019a).

In accordance with Article 24 of the regulation on unlicensed electricity generation published in the Official
Gazette dated 12.05.2019 and numbered 30,772, generation facilities established and put into operation before the new regulation will continue to benefit from $13.3 \$$ cents $/ \mathrm{kWh}$ for the first ten years of operation. The electricity purchase price of the facilities that will come into operation after this date will be the same retail price as the electricity purchase price of the relevant consumption facility (OG 2019b).

\section{Licensed generation model}

Regardless of their source, electrical power plants with an installed power capacity of $5 \mathrm{MW}$ and larger are installed and operated with a licensed generation model. For solar and wind energy installations, an application for an associate license is required at the first stage. The prerequisite for the application is to allocate and to announce the capacity by Turkish Electricity Transmission Corporation (TEIAŞ) for the region selected for the power plant installation. It is also compulsory for applicants to have at least one-year on-site measurement data collected in the last five years of the region.

Investors applying to EMRA for the same network connection point/region are subject to a tender process asking for a discount on the RES Support Mechanism (YEKDEM) tariffs (OG 2005). The winners of the tender benefit from the discounted YEKDEM tariff instead of the fixed tariff for the first ten years of operation. However, the rights of domestic production material incentives brought by the Law No. 5346 are reserved and that incentive is utilized over the YEKDEM tariff. Capacity allocation is valid only for licensed solar and wind plant installations. There is no such allocation requirement for other renewable source power plant installations (OG 2002).

The Renewable Energy Resource Areas Regulation (YEKA) was published by the Ministry of Energy and Natural Resources (ETBK) on October 9, 2016. The regulation aims to support renewable energy investments, to encourage the use of renewable generation assets, to increase the use of domestic equipment/components and to contribute to research and development activities through technology transfer. While licensed projects benefit from discounted tariffs and local production support over YEKDEM prices in accordance with the Law No.5346, the bidding process for YEKA projects calls for a discount from both the YEKDEM price and a certain price ceiling that includes local content support. Accordingly, the winner of the YEKA competition is not entitled to extra local production support. However, in YEKA projects, the supports are determined as fifteen years, not ten years, unlike other RES projects (OG 2016). 


\section{Incentive policies}

In general, countries use support mechanisms for the development and dissemination of RES. The common and primary goal is to reach emission targets by increasing the use of RES (Ramirez et al. 2017). Support mechanisms are implemented as a specific support or a mix of multiple supports (EUROSTAT 2020). The most commonly used RES support mechanisms used by countries are given below (Council of European Energy Regulators 2018):

- Feed-in Tariff: This tariff provides a government guarantee to purchase electricity generated from determined RES at a determined price per $\mathrm{kWh}$ for a specified period of time.

- Feed-in Premium: This tariff is also a government-guaranteed tariff where the producer receives payment per $\mathrm{kWh}$ above the wholesale electricity price.

- Investment subsidies: This mechanism includes investment support for a certain percentage of renewable energy generation.

- Tax incentives: This mechanism offers exemption or reduction in taxes, VAT rates or amortization schedules.

- Green certificates: These certificates are tradable commodities to prove that certain amount of the electricity is generated using RES.

- Research and Development (R and D) incentives: $R$ and $D$ incentives are supports given for certain $R$ and $D$ studies.

- Call for tenders: The government calls for tenders to increase electricity generation from RES. This mechanism provides contract-based generation with a purchase guarantee at the tender price.

In Turkey, various incentive policies are implemented in order to increase renewable energy utilization similar to the countries of the world. The incentives applied are listed below.

\section{Feed-in tariffs (FiTs)}

The tariff-based incentive application first started with the Law No. 5346. The law provides a purchase guarantee for renewable energy-based electricity generation. According to the support mechanism, licensed and unlicensed facilities which started to generate electricity from renewable sources before December 31, 2020, are able to benefit from the tariffs in Table 4 for a maximum of 10 years from the date of operation (OG 2005).

Schedule I, published in the Official Gazette dated January 30, 2021 and numbered 31,380, redefined support rates (OG 2021). Current rates are given in Table 5. The application covers the RES certificated electricity generation
Table 4 Turkish feed-in tariffs for renewable-based power generation (OG 2005)

\begin{tabular}{ll}
\hline Generation type & $\begin{array}{l}\text { Feed-in tariff } \\
(\$ \text { cent/kWh })\end{array}$ \\
\hline Hydropower & 7.3 \\
Wind & 7.3 \\
Geothermal & 10.5 \\
Biomass & 13.3 \\
$\quad$ (including & \\
$\quad$ landfill gas) & \\
Solar & 13.3 \\
\hline
\end{tabular}

facilities to be put into operation from 01/07/2021 to $31 / 12 / 2025$. Prices given in Annex-1 of the Schedule I are applied during the specified periods (Table 5). The duration of YEKDEM was determined to remain as ten years. The domestic contribution price was fixed at 8 Turkish lira kuruş/ $\mathrm{kWh}$ with a support period of five years. Prices given in Table 5 are updated quarterly according to the method given below. An upper limit to be considered in updating RES Support Mechanism Prices in USD was also determined for each resource (Table 6).

\section{Support for domestic production content}

Law No. 5346 provides domestic production content support for domestic equipment used in RES licensed production facilities plants commissioned before 01/07/2021. Facilities generating electricity according to the unlicensed generation model are not within the scope of the support. A component must have a local content of at least $55 \%$ in order to be included in the scope of the incentive. However, this is not sufficient to fully qualify for the incentive. If the investor meets the 55\% minimum threshold for a component, 55\% of the incentive is awarded. For each component above 55\% domestic content rate, the prices specified in the Schedule II attached to the Law are given to the investor as an additional incentive for a period of five years (Table 7) (OG 2011a). Domestic production content support for RES facilities which are operational from 01/07/2021 to 31/12/2025 was changed for all resource types as 8 Turkish lira kuruş/kWh. As given in Table 5, the domestic production content period was determined as five years (OG 2021). Domestic production content rates are updated quarterly as well as prices.

\section{Land acquisition}

Forested areas, lands belonging to the Treasury or lands completely disposed of by the government can be used for renewable energy production, with the permission of the Ministry of Agriculture and Forestry or the Ministry of Treasury and Finance. Other collections arising from the use of government-owned land are not collected from renewable energy generation facilities. Rental, right of use permission 
Table 5 YEKDEM support mechanism to become operational from 01/07/2021 to 31/12/2025 and additional incentives for domestic components (OG 2021)

\begin{tabular}{lllll}
\hline Type of Renewable Energy Source & $\begin{array}{l}\text { YEKDEM price } \\
\text { (Turkish liras kuruş/ } \\
\text { kWh) }\end{array}$ & $\begin{array}{l}\text { YEKDEM price } \\
\text { application Period } \\
\text { (year) }\end{array}$ & $\begin{array}{l}\text { Domestic components support } \\
\text { price (Turkish liras kurus/kWh) }\end{array}$ & $\begin{array}{l}\text { Domestic components } \\
\text { support application period } \\
\text { (year) }\end{array}$ \\
\hline a. Hydroelectric energy & 40 & 10 & 8 & 5 \\
b. Wind energy & 32 & 10 & 8 & 5 \\
c. Solar energy & 32 & 10 & 8 & 5 \\
\hline
\end{tabular}

Table 6 Upper limit to be considered in updating YEKDEM (OG 2021)

\begin{tabular}{ll}
\hline Type of renewable energy source & $\begin{array}{l}\text { Upper limit for } \\
\text { updating }(\$ \text { cent/ } \\
\mathrm{kWh})\end{array}$ \\
\hline a. Hydroelectric energy & 6.4 \\
b. Wind energy & 5.1 \\
c. Solar energy & 5.1 \\
\hline
\end{tabular}

fees will be applied at a discount rate of $85 \%$ in the first ten years for renewable energy facilities that are connected to power transmission lines, including the ones currently in operation (OG 2007).

\section{Incentives for pre-license/license/system usage fees and taxes}

In accordance with the relevant article of the electricity license regulation, facilities generating electricity from local natural resources and renewable resources are exempt from annual license fees for the first eight years following the completion date. Temporary Article 4 of the Electricity Market Law No. 6446 also provides 50\% discount for any generation facility (including renewable energy-based facilities) to be operational until 31 December 2025 to the usage of transmission lines during the first five years (OG 2013).

\section{Investment incentives}

In accordance with the decision of the Council of Ministers on "State Aid for Investments" numbered 2012/3305, renewable energy generation facilities benefit from the General Investment Incentive Plan which includes exemption from value added tax (VAT) and customs taxes for all machinery and equipment used in the relevant power plant. Regardless of the region of the investment, all projects which meet both the special capacity conditions and the minimum fixed investment amount are supported within the framework of the General Investment Incentives Program. However, the General Incentive Program is only applied for the facilities using domestically produced panels. Customs duty exemption for imported machinery and equipment and VAT exemption for imported or domestically purchased machinery and equipment stand out as incentives provided in the case of using an "investment incentive certificate" (OG 2012a, 2012b).

Table 7 Additional solar power incentives for domestic components (OG 2011a)

\begin{tabular}{|c|c|c|}
\hline Generation type & Domestic component & $\begin{array}{l}\text { Additional incen- } \\
\text { tive }(\$ c e n t / \mathrm{kWh})\end{array}$ \\
\hline \multirow[t]{5}{*}{ Photovoltaic solar power } & PV panel integration and solar structural mechanics production & 0.8 \\
\hline & PV modules & 1.3 \\
\hline & Cells forming the PV modules & 3.5 \\
\hline & Inverter & 0.6 \\
\hline & Material focusing the solar rays onto the PV module & 0.5 \\
\hline \multirow[t]{7}{*}{ Intensified solar power } & Radiation collection tube & 2.4 \\
\hline & Reflective surface plate & 0.6 \\
\hline & Sun chasing system & 0.6 \\
\hline & Mechanical accessories of heat energy storage system & 1.3 \\
\hline & $\begin{array}{l}\text { Mechanical accessories of steam production system that collects the sun rays on } \\
\text { the tower }\end{array}$ & 2.4 \\
\hline & Stirling engine & 1.3 \\
\hline & Panel integration and solar panel structural mechanics & 0.6 \\
\hline
\end{tabular}




\section{Net metering}

Netting (offsetting) practice in Turkey first started with the Law No.5346 (OG 2005). Netting support, which started on an hourly basis, started to be implemented as monthly netting in accordance with the CK in 2019. New net metering support conditions have been changed and applicable for roof and facade applied systems. YEKDEM production facilities will be able to benefit from net metering supports. These units will be able to benefit from support for installed power as well as link agreement power. Also, production and consumption must be done from the same measuring point. Net metering support is limited to $10 \mathrm{~kW}$ for residential prosumer. Commercial and lighting subscribers will benefit from the support for the installed power as much as the contract power.

The retail one-time active energy price announced by EMRA for the surplus electricity produced is applied for a period of ten years from the date of operation of the facility (OG 2019a). Until the last regulation, the net electricity delivered to the grid from rooftop solar energy systems was evaluated on an hourly basis. In addition, excess electricity generation from solar energy was not allowed to be used in other time periods. The only contribution of the previous regulation was that individual household users were able to use the electricity generated from the sun in a certain time to reduce the electrical energy delivered from the grid. The new regulation for netting calculates the amount of electricity supplied to the grid and the amount demanded from the grid on a monthly basis. Thus, prosumers monitor the amount of solar energy-based electricity supplied to the grid and the amount of electricity delivered from the grid for a whole month. Monthly netting aims to make roof installations attractive by supplying electricity to the grid at the current electricity unit price in case of overproduction and reducing electricity consumption to be reflected in the total bill in case of overconsumption (OG 2019a).

\section{Solar energy in Turkey}

In parallel with the legal regulations regarding electricity generation from RES and the accompanying incentive arrangements, the share of RES in the total electricity installed power is increasing rapidly. By the end of September 2020, the ratio of the total installed power of RES in the total installed power increased to $49.7 \%$ with an installed capacity of 46,611.4 MW (2030 Climate Target Plan 2020). The total installed capacity of solar energy reached to $6361 \mathrm{MW}$. Figure 4 gives the change in installed power of solar energy systems over the years. Since 2014, a rapid increase has been observed in the installed power of solar energy systems and the number of power plants. The competitiveness of solar power plant installations with legal regulations and incentives and the cost reductions in PV module unit prices worldwide triggered solar investments. Figure 5 presents the decrease in PV module prices over the years. According to the figure, significant decreases up to $90 \%$ were observed in module prices between the end of 2009 and the end of 2018. This improvement in module prices made solar power plant installation costs competitive with conventional power plants and even cheaper for some technologies (IRENA 2019).

Increasing the installed capacity of unlicensed electricity generation to $1 \mathrm{MW}$ with the Law No. 6446 (EPK) and the new incentive mechanism led to a rapid increase in unlicensed solar power plant generation applications in the solar energy market. In the first stage, unlicensed solar power
Fig. 4 Installed solar power change by years (TEIAS 2020b)
Installed Capacity (MW)

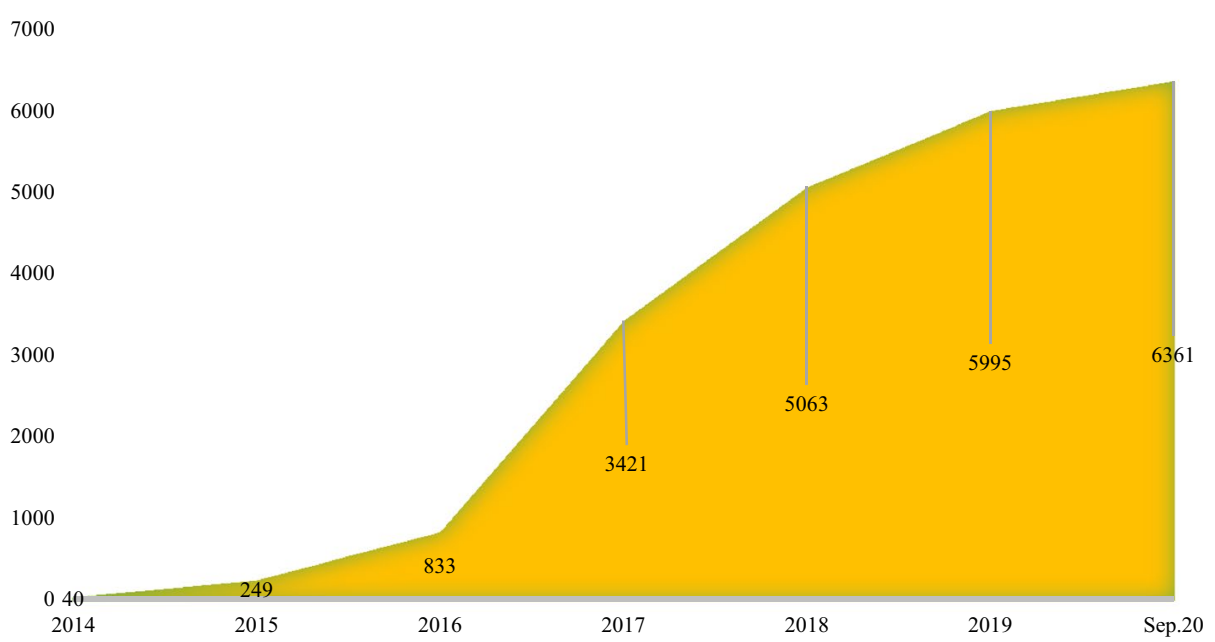




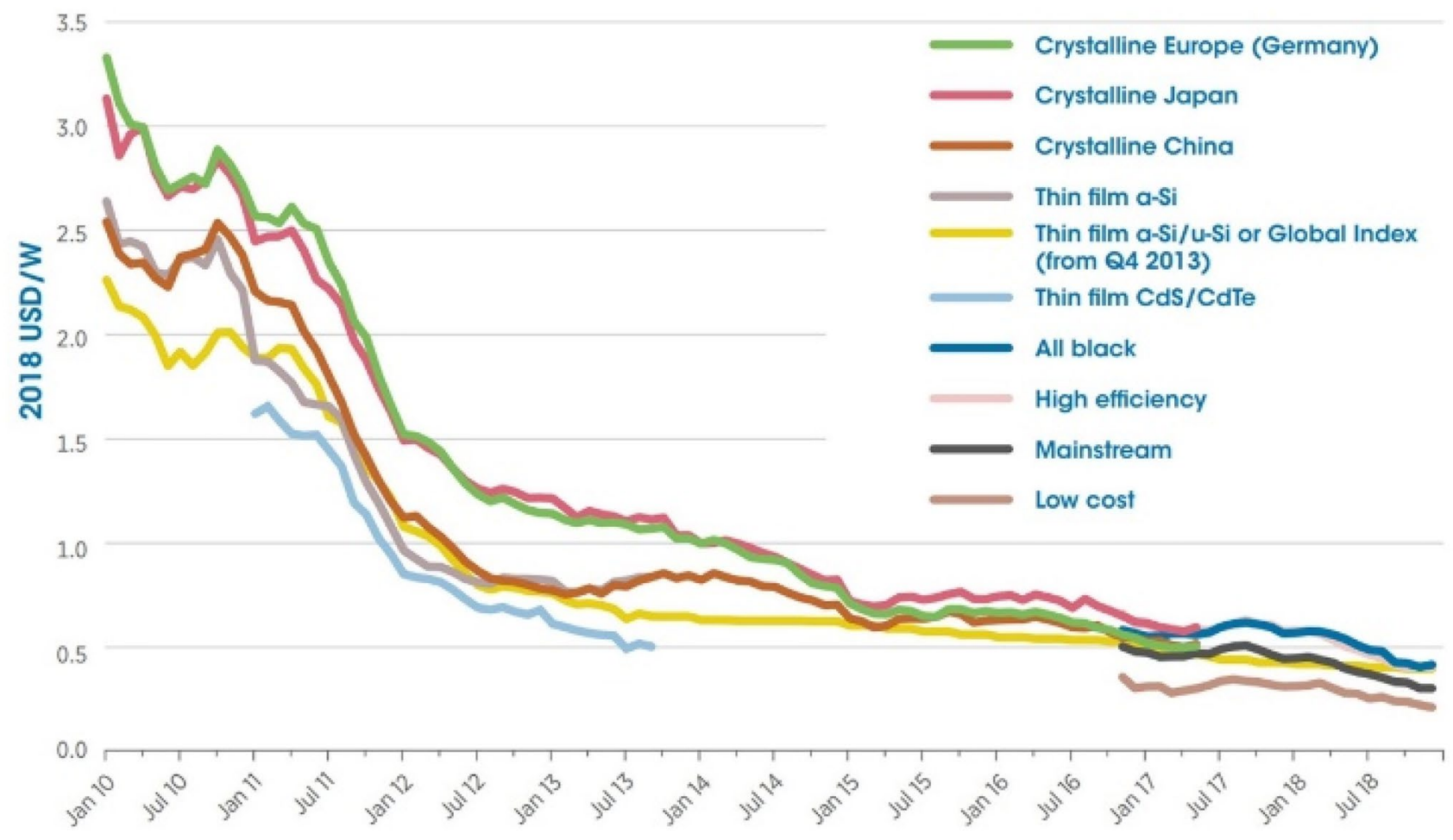

Fig. 5 Average monthly European solar PV module prices by module technology and manufacturer, January 2010-July 2018 (IRENA 2019)

plants were mostly installed on land. Figure 4 indicates that rapid increases occurred in the number and capacity of solar power plants in 2016 and 2017 with the formation of favorable market conditions. By the end of September 2020, 7242 unlicensed solar power plants were recorded with a total installed power of $6102.3 \mathrm{MW}$. For the relevant period, the ratio of unlicensed solar power plants in the total solar power plants reached $95.93 \%$, and the ratio in the total installed power reached $6.5 \%$ (TEIAS 2020b).

After the YEKK was published, interest in licensed solar energy investments in Turkey started to increase rapidly. By the law, it is envisaged the creation of a licensed generation capacity of $600 \mathrm{MW}$ at the first stage. The capacity is distributed in 38 provinces in 27 regions according to the total average annual radiation values and sunshine duration. Among the provinces, the largest capacity is given to Konya (92 MW), followed by Van (77 MW) and Mersin (35 MW), respectively. By the end of September 2020, 25 licensed solar power plants were installed, and the total installed power reached a total of $258.9 \mathrm{MW}$.

Within the scope of YEKA regulation, it is planned to increase the ratio of solar and wind power generation in the total installed power through tenders. The first solar power plant of YEKA, SPP-1, was allocated in Konya-Karapınar with an installed capacity of 1000 MW. The Karapınar YEKA tender was held by ETKB with the participation of
4 consortiums, and the group with the lowest bid of 0.0699 $\mathrm{USD} / \mathrm{kWh}$ won the tender. During the project, a solar panel factory with a photovoltaic module production capacity of at least 500 megawatts per year was established. A thousand-megawatt connection capacity has been allocated for Karapinar YEKA for ten years. According to the specification, domestic content of the first 500 megawatts is required to be at least $60 \%$.

The YEKA SPP-1 project started at the beginning of 2020 , and it is planned to be put into operation at full capacity by the end of 2023. An investment of 1.1 billion dollars is planned for the project. It is expected to employ 800 people during the construction and 100 people after the operation. The size of the power plant, an area of 22 thousand hectares, is equivalent to 14 thousand 386 football fields. It is planned to use approximately 3.5 million solar panels in the $12 \mathrm{~km}$ long area. It is expected for the power plant to meet the energy demand of more than 1 million households by a total annual electricity generation of 2.5 billion $\mathrm{kWh}$. It is aimed to prevent approximately 1.5 million tons of carbon emissions per year accordingly (OG 2016).

The second YEKA tender, SPP-2, was announced by the MENR on 5 October 2018 in the Official Gazette, and it was announced that the final bids would be received on 31 January 2019. The tender was planned to be held in ŞanliurfaViranşehir, Niğde-Bor, Hatay-Erzin, for installed 
capacities of $500 \mathrm{MW}, 300 \mathrm{MW}$ and $200 \mathrm{MW}$, respectively. However, it was announced that the tender was cancelled by MENR. Sector representatives presented the current financial situation of the country and sector expectations as reasons for cancellation (GUYAD 2019).

According to the Correction Notice published in the Official Gazette within the scope of YEKA, the third YEKA tender, SPP-3, which was previously announced to be held on October 19-23, 2020, has been decided to be held on January 18-21, 2021, due to the COVID-19 pandemic. 74 bids are planned in terms of "YEKA Purpose Connection Capacity Allocation Method" and "Allocation for Use of Domestic Goods (YMKT) Method" in the third paragraph of Article 5 of the YEKA Regulation published in the Official Gazette dated 09/10/2016 and numbered 29,852. By the bids, it is aimed to reach a total solar power plant capacity of $1000 \mathrm{MW}$, with small-scale plants of $10 \mathrm{MWeq}, 15 \mathrm{MWeq}$ or $20 \mathrm{MWeq}$ in specified connection zones. The names and connection capacities of YEKA SPP-3 bids are announced on the ministry page (MENR 2020).

Turkey's geographical location and sunshine durations are extremely suitable for roof and façade-type solar energy systems. According to the data of the Turkish Statistical Institute (TUIK), there are 9.1 million buildings in Turkey and approximately $87 \%$ of this amount is residential buildings. More than 100,000 new buildings are added to Turkey's building stock every year. It is planned to install PV systems at the level of 2000-4000 MW on the roofs and facades of these buildings in the next 10 years. Table 8 presents roof applications made to MENR as of October 16, 2020 (MENR 2021a).

\section{SWOT analysis of DPPG in Turkey}

As a developing country, energy demand of Turkey has been increasing constantly. 59.14\% of this demand is met from fossil fuels and $43.14 \%$ of fossil fuels are imports (EPİAŞ 2021). Keeping energy costs at reasonable levels, reducing

Table 8 Rooftop solar energy applications end of September 2020 (MENR 2021a)

\begin{tabular}{llll}
\hline Consumer type & Periods & $\begin{array}{l}\text { Installed capac- } \\
\text { ity (MW) }\end{array}$ & Count \\
\hline Industry & Before 10/05/2019 & 670.52 & 2429 \\
& After 10/05/2019 & 2420.1 & 3697 \\
& Total & 3090.62 & 6126 \\
Residence & Before 10/05/2019 & 10.07 & 1090 \\
& After 10/05/2019 & 13.61 & 1354 \\
& Total & 23.68 & 2444 \\
Grand total & 3114.3 & 8570 & \\
\hline
\end{tabular}

dependence on imported coal and natural gas and reducing the environmental impact of fossil fuels are of great importance for the sustainability of the country's development. These concerns are valid for industrialized and developing countries, and as one of these countries, Turkey is making efforts to accelerate the transition to new and clean energy technologies. DPGG systems, on the other hand, emerge as an important alternative in meeting the increasing needs and demands.

DPPG systems are developing in Turkey as well as all over the world. The total installed power of the country is 93207.1 MW. Solar energy installed power, on the other hand, has a share of $6.82 \%$ with $6361.3 \mathrm{MW}$. Considering the annual electricity energy production values according to the sources of the relevant period given in Table 1, it is the source with the lowest share in total production with $357,670.15 \mathrm{MWh}$ and $0.12 \%$. As of the end of September 2020 , the total installed power of licensed solar power plants was recorded as $258.9 \mathrm{MW}$ with 25 in-operation power plants. Unlicensed generation, on the other hand, reached a size of 6102.3 MW with 7242 in-operation power plants. The current situation shows that the share of solar power plants in both installed power and electricity generation is quite low compared to its high potential. This paper presents a strengths $(\mathrm{S})$, weaknesses $(\mathrm{W})$, opportunities $(\mathrm{O})$ and threats (T) analysis of the Turkish DPPG sector by the current situation assessment made in the previous sections and proposes urgent strategies to accelerate the spread of DPPG systems.

According to the SWOT analysis presented in Table 9, possible strategies are recommended to boost the deployment of distributed photovoltaic power generation by seizing the opportunities and overcoming the threats (Table 10).

\section{Strength-opportunity strategy: Implementing planned and long-term incentive policies}

In order to transform the electrical energy production, which is largely dependent on imported fossil fuels, and to increase the locality rate, a special regulation and scope definition should be made for solar energy systems. It is necessary to strongly encourage the development of DPPG systems, to adopt and implement long-term, planned and systematic incentive policies. In this context, an adjustment in the retail unit electricity prices of FiTs can accelerate the local solar PV market. Besides, unlicensed land installations, which contributed greatly to the increase in the DPPG installed power implemented between 2014 and 2018, can be re-released and a new momentum can be gained in the sector. Monthly changing net-metering can also be changed to annual periods. In addition, increasing the installed power limit for roof and facade household applications which is $10 \mathrm{~kW}$ currently can raise the 
Table 9 SWOT analysis results for DPPG in Turkey

\begin{tabular}{|c|c|}
\hline Strengths & Weaknesses \\
\hline 1. Sunshine duration and solar radiation values & $\begin{array}{l}\text { 1. Lack of a separate regulation and incentive mechanism for solar } \\
\text { energy }\end{array}$ \\
\hline $\begin{array}{l}\text { 2. Legal regulations on renewable energy, FiT, net-metering, purchase } \\
\text { guarantee support, additional supports to the existing supports for the } \\
\text { domestic equipment use }\end{array}$ & $\begin{array}{l}\text { 2. Insufficient high technology production and } \mathrm{R} \text { and } \mathrm{D} \text { capacity for } \\
\text { renewable energy systems }\end{array}$ \\
\hline 3. Sufficient and qualified space for new installations & 3. High dependency on raw material imports \\
\hline 4. Geographical position & $\begin{array}{l}\text { 4. Switching from fixed dollar price to TL in FiTs } \\
\text { 5. Decrease in incentive amounts } \\
\text { 6. Currency that is constantly on the rise } \\
\text { 7. Duration of sunshine and the intensity of solar energy vary consid- } \\
\text { erably throughout the year } \\
\text { 8-Land use requirements for solar power plants }\end{array}$ \\
\hline Opportunities & Threats \\
\hline $\begin{array}{l}\text { 1. The continuous growth of the economy and the continuous increase in } \\
\text { energy demand }\end{array}$ & 1. The ambitious of distributed photovoltaic power generation targets \\
\hline 2. EU support on national annual goals & 2. Public support \\
\hline \multicolumn{2}{|l|}{ 3. Rising electricity prices } \\
\hline \multicolumn{2}{|l|}{ 4. Number of engineering and consulting companies with experience } \\
\hline 5. Decrease in installation costs & \\
\hline
\end{tabular}

Table 10 Recommended possible strategies

\begin{tabular}{lll}
\hline & Strengths & Weaknesses \\
\hline Opportunities & Implementing planned and long-term incentive policies & $\begin{array}{c}\text { Increasing government support for photo- } \\
\text { voltaic technology and R and D studies } \\
\text { Increasing complementarity among } \\
\text { renewables for seasonal fluctuations }\end{array}$ \\
Threats & $\begin{array}{c}\text { Increasing the ambitious of distributed photovoltaic power generation } \\
\text { targets }\end{array}$ & \begin{tabular}{c} 
Increasing public awareness of the DPPG \\
\hline
\end{tabular} \\
\hline
\end{tabular}

public attention in DPPG systems. Finally, users should be encouraged with long-term and interest loan supports for the rapid spread of DPPG.

\section{Weakness-opportunity strategy 1: Increasing government support for photovoltaic technology and $R$ and $D$ studies}

Currently, solar energy systems applications in Turkey are highly dependent on foreign solar PV markets. The low domestic production rate of the basic components of distributed photovoltaic power generation systems causes the cost of DPPG applications to be greatly affected by exchange rate changes. This situation adversely affects long-term planning and investments and slows down the increase the share of DPPG systems in installed capacity. It is necessary to develop the ongoing local component use support and to make long-term planning for improving the scope of $\mathrm{R}$ and D studies for solar components.

\section{Weakness-opportunity strategy 2: Increasing complementarity among renewables for seasonal fluctuations}

$40.86 \%$ of Turkey's electrical energy production is met from renewable energy sources. Hydroelectric energy has the largest share among renewable energy sources with $69.08 \%$, while wind energy comes as the second with $19.68 \%$ share. When the sunshine duration and intensity of solar energy decrease, the probability of rainy season increases and a dramatic raise in wind regime occurs. Hydroelectric and wind energy production takes place at the highest level and efficiency in the months when solar energy is minimal. Talking for Turkey, in the period from May to September, sunshine duration and solar intensity are at their highest, while hydro- and wind power generation are at their lowest; the opposite is experienced from December to April. Therefore, it is possible to bend to hydro-solar and wind-solar hybrid approaches in Turkey to provide seasonal energy complementarity applications. 


\section{Strength-threat strategy: Increasing the ambitious of distributed photovoltaic power generation targets}

The national solar energy strategies of Turkey within the sustainable development plans need to be defined more clearly and ambitiously urgently. However, the more ambitious natural gas security strategies may risk the emission reduction targets of the country.

\section{Weakness-threat strategy: Increasing public awareness of the DPPG}

Increasing the awareness of all members of the society toward solar energy is very important for DPPG systems to spread and gain a great momentum. In order to change the prejudice, anxiety and misconception of the public against solar energy systems, information should be provided and access to information should be facilitated. For this purpose, government can organize seminars cooperating with universities and local governments to improve and examine the public response toward solar energy systems.

\section{Conclusion}

It is a fact that Turkey is heavily dependent on fossil fuels to meet its energy demand. The natural gas has the largest share among the fossil fuels that the country utilizes in energy generation. Billions of dollars of energy imports are realized every year. This heavy dependence on energy imports both jeopardizes the energy independence and causes the current account deficit to increase.

Grid-connected PV systems are advantageous for Turkey compared to many EU countries in terms of solar radiation and sunshine duration due to the country's geographical location. Therefore, there is a potential to diversify electrical energy sources. However, some technical, financial and political obstacles prevent the widespread use of PV systems.

Turkey's solar energy data show that there was no significant growth in installed solar power plant capacity until 2014. However, a rapid growth was observed with the effect of the regulations made between 2014 and 2018. The total installed solar power plant capacity was recorded $5064 \mathrm{MW}$ by the end of 2018. The rapid increase between 2014 and 2018 slowed down and almost came to a standstill until mid-2019, due to the effects such as cancelling the land supports of unlicensed power plants, narrowing the scope of incentives and excessive exchange rate increase. Regulations regarding roof and facade SPP applications were completed by the middle of 2019. The regulations introduce monthly netting for roof-type solar power plant investments. A number of pre-approval applications prove that a rapid and continuous increase in the installed power and number of solar power plants is likely in the following years through new regulations.

The sudden increase in the installed capacity since 2015 indicates that the incentive policies of DPPG systems are effective. However, the slowdown that occurred after 2019 is also directly related to incentive policies. At the end of 2018, unlicensed land solar power plant installation incentives were terminated. With the decision of January 31,2021 , the FiT rate for the next five years was reduced from $13.3 \$$ cents $/ \mathrm{kWh}$ to a maximum of $5.1 \$$ cents $/ \mathrm{kWh}$. Considering the relationship between installed power and incentive policies in the past years, a sudden decrease in installations may occur.

This paper conducts a SWOT analysis based on situation all these excellences and shortcomings in different stages of distributed photovoltaic power generation development in the country. The results of the SWOT analysis indicate that the spread of DPPG can be accelerated with an emergency action plan based on four urgent strategies given below:

- Implementing planned and long-term incentive policies

- Increasing government support for photovoltaic technology and R and D studies

- Increasing complementarity among renewables for seasonal fluctuations

- Increasing the ambitious of distributed photovoltaic power generation targets

- Increasing public awareness of the DPPG

The SO Strategy, "Implementing Planned and Long-Term Incentive Policies," aims to address the economical concerns of the national PV market and to define a special regulation and scope for solar energy systems to accelerate the development DPPGs within national and global sustainable development goals. Besides, the WO Strategy 1, "Increasing Government Support for Photovoltaic Technology and $\mathrm{R}$ and D Studies," emphasizes the significance of encourage domestic production of the basic components of distributed photovoltaic power generation systems for long-term planning and investments. On the other hand, the WO Strategy 2, "Increasing Complementarity among Renewables for Seasonal Fluctuations," focuses on seasonal adjustment of large-scale DPPG system applications. The strategy suggests to bend to hydro-solar and wind-solar hybrid approaches to overcome the DPPG system losses due to seasonal fluctuations. The ST Strategy, "Increasing the Ambitious of Distributed Photovoltaic Power Generation Targets," remarks the urgency of redefining solar targets to sustain the emission reduction targets of the country. Finally, the WT Strategy, "Increasing public awareness of the DPPG," underlines 
the role of public response to spread DPPG systems with a greater momentum.

\section{References}

BP Energy Outlook (2018) 2018 Edition.https://www.bp.com/conte nt/dam/bp/business-sites/en/global/corporate/pdfs/energy-econo mics/energy-outlook/bp-energy-outlook-2018.pdf.April 2021

BP Energy Outlook (2019) 2019 Edition. https://www.bp.com/conte nt/dam/bp/business-sites/en/global/corporate/pdfs/energy-econo mics/energy-outlook/bp-energy-outlook-2019.pdf. April 2021

BP Energy Outlook (2020) 2020 Edition. https://www.bp.com/conte nt/dam/bp/business-sites/en/global/corporate/pdfs/energy-econo mics/energy-outlook/bp-energy-outlook-2020.pdf. April 2021

Brass JN, Carley S, MacLean LM, Baldwin E (2012) Power for development: a review of distributed generation projects in the developing world. Annu Rev Environ Resour 37:107-136

2030 Climate Target Plan (2020) The 2030 climate and energy framework includes EU-wide targets and policy objectives for the period from 2021 to 2030. https://ec.europa.eu/clima/policies/ strategies/2030_en. April 2021

Council of European Energy Regulators (2018) Status Review of Renewable Support Schemes in Europe for 2016 and 2017. Brussels, Belgium https://www.ceer.eu. January 2021

Official Gazette Number: 26510 (2007) Energy Efficiency Law No. 5627. https://www.resmigazete.gov.tr/ January 2021.

EPİAŞ (2021) Real-Time Electrical Power Generation Reports. https:// seffaflik.epias.com.tr/transparency/uretim/gerceklesen-uretim/gercek-zamanli-uretim.xhtml. September 2021

EurObserv'ER (2020) Photovoltaic barometer 2020. https://www.eurob serv-er.org/photovoltaic-barometer-2020 January 2021.

European Commission (2020) 2020 report on the State of the Energy Union pursuant to Regulation (EU) 2018/1999 on Governance of the Energy Union and Climate Action. Brussels COM (2020) 950 final.

European Union (2009) The promotion of the use of energy from renewable sources and amending and subsequently repealing Directives 2001/77/EC and 2003/30/EC. Official Journal of the European Union https://eur-lex.europa.eu/legal-content/EN/TXT/ PDF/?uri=CELEX:32009L0028\&from=EN January 2021.

EUROSTAT (2020) Simplified energy balances https://ec.europa.eu/ eurostat/databrowser/view/NRG_BAL_S_custom_526506/defau 1t/table?lang=en January 2021.

GUYAD (2019)http://www.guyad.org/EN,185/yeka-2-ges-ihalesihakkinda.html January 2021.

Hoff TE, Perez R, Margolis RM (2007) Maximizing the value of customer-sited PV systems using storage and controls. Sol Energy 81(7):940-945

IEA (2020a) Renewables 2020 Data Explorer, OECD/IEA, Paris, France. https://www.iea.org March 2021.

IEA (2017a) Energy Technology Perspectives, OECD/IEA, Paris, France. https://www.iea.org June 2020

IEA (2017b) Medium-Term Renewable Energy Market Report 2016, OECD/IEA, Paris, France. https://www.iea.org March 2021.

IEA (2019a) Solar Heat worldwide, OECD/IEA, Paris, France. https:// www.iea.org April 2021.

IEA (2019b) National Survey Report of PV Power Applications in JAPAN 2019, OECD/IEA, Paris, France. https://www.iea-pvps. org. January 2021.

IEA (2020b) Snapshot of Global PV Markets 2020, OECD/IEA, Paris, France. https://www.iea-pvps.org January 2021.

IEA (2020c) Countries: Turkey, OECD/IEA, Paris, France. https:// www.iea-pvps.org January 2021.
IFC (2017) Energy Storage Trends and Opportunities in Emerging Markets https://www.esmap.org/sites/default/files/esmap-files/ 7151-IFC-EnergyStorage-report.pdf March 2021.

IRENA (2019) Renewable Power Generation Costs in 2018, International Renewable Energy Agency, Abu Dhabi.

Kirova M, Velikova P (2016) Risk management method for small photovoltaic plants. Manag Mark 11:3

Li M (2017) Analysis of the development trend of the distributed power station from the photovoltaic policy. Power World 12:8

Li H, Lin H, Tan Q, Wu P, Wang C, De G, Huang L (2020) Research on the policy route of China's distributed photovoltaic power generation. Energy Rep 6:254-263

MENR (2019) 2019-2023 strategic plan. MENR, Ankara https:// sp.enerji.gov.tr/ETKB_2019_2023_Stratejik_Plani.pdf January 2021.

MENR (2020) https://enerjiapi.etkb.gov.tr/media/common/0b9b0 7d7-a639-424c-9b24-d4323ba8b4b2_YEKA_GES_3_RG_ ILAN_METNI_03_07_2020.pdf January 2021.

MENR (2021a) Solar Energy https://enerji.gov.tr/eigm-yenilenebi lir-enerji-kaynaklar-gunes June 2021.

MENR (2021b) Turkey Solar Energy Potential Atlas https://www. yegm.gov.tr/ June 2021.

Official Gazette Number: 24836 (2002) The Electricity Market License Regulation https://www.resmigazete.gov.tr January 2021.

Official Gazette Number: 25819 (2005) Law no 5346 Regarding the Use of Renewable Energy Sources For Electric Energy Generation https://www.resmigazete.gov.tr/eskiler/2019/05/20190512-1. htm January 2021.

Official Gazette Number: 27969 (2011a) The Regulation Regarding Local Manufacture of the Components Used in the Generation of Electricity from Renewable Energy Resources. https://www.resmi gazete.gov.tr January 2021.

Official Gazette Number: 28001 (2011b) The Regulation Regarding Unlicensed Power Generation in relation to the Electricity Market. https://www.resmigazete.gov.tr/ January 2021.

Official Gazette Number: 28328 (2012a) Decision No. 3305 on State Aids in Investments. https://www.resmigazete.gov.tr January 2021.

Official Gazette Number: 28329 (2012b) Communiqué on Implementation of The Decision on Government Aid in Investments. https:// www.resmigazete.gov.tr January 2021.

Official Gazette Number: 28603 (2013) Electricity market license regulation no 6446. https://www.resmigazete.gov.tr January 2021.

Official Gazette Number: 29852 (2016) Regulation on Renewable Energy Resource Areas. https://www.resmigazete.gov.tr/ January 2021.

Official Gazette (2017) Energy Market Regulatory Authority (EMRA) published the board decision dated 28/12/2018 and numbered 7590. https://www.resmigazete.gov.tr/eskiler/2018/01/201801189.pdf January 2021.

Official Gazette Number: 30770 (2019a) Attachment to the President's Decision Dated 09/05/2019 and Numbered 1044. https://www. resmigazete.gov.tr/ January 2021.

Official Gazette Number: 30772 (2019b) Unlicensed Electricity Generation Regulation in the Electricity Market https://www.resmi gazete.gov.tr/eskiler/2019/05/20190512-1.htm January 2021.

Official Gazette Number: 31174 (2020) YEKA GES-3. https://www. resmigazete.gov.tr/ January 2021.

Official Gazette Number: 31380 (2021) https://www.resmigazete.gov. tr/eskiler/2021/01/20210130-9.pdf January 2021.

Özenç B (2020) The feasibility of coal in the renewable energy era: the example of Hunutlu thermal power plant. https://wwftr.awsassets. panda.org/downloads/hunutlufinansal_analiz_tr.pdf January 2021.

British Petroleum (2019) Statistical Review of world energy. 68th edition 2019, https://www.bp.com/content/dam/bp/business-sites/ 
en/global/corporate/pdfs/energy-economics/statistical-review/ bp-stats-review-2019-full-report.pdf. January 2021

Ramirez FJ, Escribano AH, Lazaro EG, Pham DT (2017) Combining feed-in-tariffs and net-metering schemes to balance development in adoption of photovoltaic energy: comparative economic assessment and policy implications for European countries. Energy Pol 102:440-452

REN21 (2020) Renewables 2020 Global Status Report. Paris REN21 Secretariat https://www.ren21.net March 2021.

Sensoy S, Ulupınar Y, Demircan M, Alan I, Akyurek Z, Bostan PA (2010) Modeling solar energy potential in Turkey. BALWOIS 2010 Ohrid Republic of Macedonia.

Strategy and Budget Department (2019) Eleventh Development Plan (2019-2023) https://www.sbb.gov.tr/wp-content/uploads/2019/07/ OnbirinciKalkinmaPlani.pdf January 2021.
TEDAS (2018) 2017 Yılı Sektör Raporu, https://www.tedas.gov.tr/sx. web.docs/tedas/docs/faaliyetrapor//Tr_Web_Versiyon_Tedas_ 2017_Faaliyet_raporu.pdf January 2021.

TEIAS (2020a) 10 Yillık Talep Tahminleri Raporu (2021-2030). https://teias.gov.tr/tr-TR/ilgili-raporlar January 2021.

TEIAS (2020b) Türkiye Kurulu Gücü Eylül 2020 sonu https://www. teias.gov.tr/tr-TR/kurulu-guc-raporlari January 2021.

Turkish Statistical Institute (2018a) https://tuik.gov.tr/ January 2021.

Turkish Statistical Institute (2018b) Population Projections 2018-2080 https://tuik.gov.tr/ January 2021.

Waldau AJ (2019) Snapshot of Photovoltaics. Energies 12(769):1-7

Publisher's Note Springer Nature remains neutral with regard to jurisdictional claims in published maps and institutional affiliations.

\title{
Authors and Affiliations
}

\author{
Mehmet Çeçen ${ }^{1,3}$ (1) Cenk Yavuz ${ }^{2,3} \cdot$ Ceyda Aksoy Tırmıkçı ${ }^{2,3} \cdot$ Sinan Sarıkaya ${ }^{4} \cdot$ Ertan Yanıkoğlu $^{3}$ \\ Mehmet Çeçen \\ mehmet.cecen@selcuk.edu.tr \\ 1 Ilgin Vocational School, Selcuk University, Konya, Turkey \\ 3 Electrical and Electronics Eng. Department, Sakarya \\ University, Sakarya, Turkey \\ 4 Eastern Anatolia Development Agency, Van, Turkey
}

2 Innovation Center of Sakarya University, Sakarya, Turkey 